\title{
24
}

\section{Regulating sex in peace operations}

\section{Gabrielle Simm}

\section{DynCorp in Bosnia}

DynCorp is a large private military and security company that was contracted by the US Government to provide police trainers and advisers to the United Nations (UN) mission in Bosnia in the late 1990s (Simm 2013). Despite the company's role in policing and training police, some employees were implicated in trafficking women and girls to Bosnia from Russia, Moldova, Romania, Ukraine and other Eastern European countries. At the time it was estimated that international personnel accounted for 30-40 per cent of clientele and approximately 70 per cent of the revenue from trafficking in Bosnia (Mendelson 2005). Media reports indicated that some DynCorp employees purchased trafficked women and children as well as benefiting from free sex in brothels. Evidence of the involvement of some DynCorp employees came from two whistleblowers, Kathryn Bolkovac and Ben Johnston.

Kathryn Bolkovac was employed in April 1999 by DynCorp to work as a police monitor in Bosnia. An experienced police officer from Nebraska, USA, she had particular expertise in child abuse and sexual assault

1 This chapter is based on Simm (2013). 
cases. ${ }^{2}$ Bolkovac became aware of widespread trafficking of women and girls into Bosnia by organised crime groups and that international personnel were involved. According to local police, trafficking had not existed prior to the arrival of international peacekeepers (LloydRoberts 2002). Bolkovac sent emails to around 50 recipients in the United Nations and DynCorp describing in graphic detail the abuses perpetrated against trafficked women and girls. She alleged that women and girls were smuggled into Bosnia 'to work as dancers, waitresses, and prostitutes', forced to perform sex acts on customers to pay debts and, if they refused, they were 'locked in rooms without food for days, beaten and gang raped by the bar owners and their associates' (Wilson 2002). She alleged that the clientele of these women included "some" local people, SFOR [Stabilisation Force] and IPTF [International Police Task Force] personnel, local Police and international/humanitarian employees in Bosnia-Herzegovina'. ${ }^{3}$ Following the email, Bolkovac was redeployed to another area and, in April 2001, she was dismissed. Bolkovac won her unfair dismissal case against the company, with the UK Employment Tribunal holding that DynCorp's explanation was 'completely unbelievable' and that it had 'no doubt whatever that the reason for her dismissal was that she made a protected disclosure' under the UK legislation protecting whistleblowers. ${ }^{4}$ The tribunal awarded Bolkovac $£ 110,000$ (about AU $\$ 305,000$ at the time) compensation for unfair dismissal. Bolkovac's story has been made into a feature film titled The Whistleblower (Kondracki 2010), based on the book by Bolkovac (with Lynn 2011).

Ben Johnston, a former US Army aircraft mechanic employed by DynCorp in Bosnia, made internal complaints about company employees who boasted about 'buying and selling women for their own personal enjoyment' and about the 'various ages and talents of the individual slaves they had purchased' (O'Meara 2002: 12). Johnston reported that at DynCorp 'a lot of people said you can buy a woman and how good it is to have a sex slave at home' (Human Rights Watch 2002: 66). DynCorp's site supervisor at the US military's Comanche Base, Bosnia, John Hirtz, videotaped himself having sex with two women, one of whom was clearly saying 'no'. Hirtz later admitted to having raped one of the women. Kevin Werner, another DynCorp employee, admitted

2 Bolkavac v DynCorp Aerospace Operations (UK) Ltd (2002) Employment Tribunals Case No. $3101729 / 01$.

3 ibid.

4 ibid. 
purchasing a weapon and a woman from a brothel owner and left Bosnia as a result of the weapons charge (US Inspector-General 2003). Another DynCorp employee, Richard Ward, told Johnston he could purchase a woman for him.

He says he'll get me one for you-you can have one for 100 marks a night or buy them for two or three thousand marks. They can be yours, and they can be your 'hoes'. (Deposition of Benjamin Dean Johnston, Ben Johnston v DynCorp Inc., District Court, Tarrant County, Texas, 20 March 2001, pp. 50-2, cited in Human Rights Watch 2002)

When DynCorp took no action on his complaints, Johnston approached the US Criminal Investigation Command, which substantiated some of his allegations (Capps 2002). Johnston also alleged that the company 'turned a blind eye' to the involvement of DynCorp personnel in purchasing women and that their involvement in trafficking continued despite the army investigation. In June 2000, DynCorp fired Johnston 'for "misconduct, violation of standards and conditions of employment and employment agreement" by bringing "discredit to the Company and the U.S. Army while working in Tuzla, Bosnia and Herzegovina"'(Human Rights Watch 2002: 66). DynCorp was reluctant to fire the employees about whom Johnston had complained. The US State Department intervened to ensure that some employees were dismissed and repatriated (US Department of State 2002). In August 2000, Johnston sued DynCorp in a federal district court in Texas. The case settled in August 2002, two days before it was due to go to trial and hours after Bolkovac won her case against the company in the United Kingdom.

Despite evidence from whistleblowers, corroborated by US Army investigations, no members of the international police taskforce were prosecuted for trafficking in Bosnia; they were instead repatriated (Evidence of Martina Vandenberg, in US Congress 2002; Andreas 2009). US Army investigators found they did not have jurisdiction over civilian contractors so they referred the case to Bosnian police. Bosnian police were apparently unsure whether the contractors benefited from immunity under the Dayton Peace Accords so did not prosecute them. At least 13 DynCorp employees were repatriated from Bosnia, at least seven of whom were fired for 'purchasing women, many of them underage, or participating in other sex trafficking activities' (Feminist Majority Foundation 2002). DynCorp nevertheless kept its contract 
with the US Government to provide police to Bosnia. An inquiry by a subcommittee of the US Congress heard evidence from David Lamb, a former UN human rights investigator in Bosnia:

an astonishing cover-up attempt ... seemed to extend to the highest levels of the UN headquarters ... The Department of State purposefully distances itself from US IPTF members by hiring DynCorp as the middle man and makes no attempt to know anything about the activities of its IPTF officers who are serving as representatives and Ambassadors of the United States. (Evidence of David Lamb, US Congress 2002: 35)

The case of DynCorp illustrates the range of actors involved in peace operations. Individual personnel include private military contractors working as UN police, diplomats, international humanitarian workers and local police. Entities whose personnel were implicated were international organisations (such as the United Nations and the North Atlantic Treaty Organization (NATO)), private corporations (DynCorp and others), sending states (whose diplomats and military were representing their governments, and aid workers whom the government might not have known were there) and the host state (Bosnian police and government officials). While there are layers of law regulating some of these actors, such as military peacekeepers, who are bound by the laws of their sending state and military discipline, they benefit from immunity from the host state's law for crimes they commit in that country. Other actors, such as foreign aid workers, are unlikely to benefit from any legal immunity but are rarely prosecuted for any crimes they commit, suggesting they benefit from impunity in practice. The variation in regulation of different categories of personnel, depending partly on which organisation employs them, raises questions about the regulation of sex in peace operations.

\section{Regulatory studies and sex in peace operations}

How are regulatory studies relevant to situations such as the sex trafficking perpetrated by some DynCorp employees in Bosnia? Sexual crimes committed in peace operations might be seen as a human rights abuse, a problem of criminal impunity, an issue of violence against women or an example of sexual abuse of children. All of these could, and perhaps should, be dealt with by a combination of international and domestic human rights law and criminal law. Sex, not amounting to sexual 
crimes, is already highly regulated, by social mores, religious doctrine, organisational codes of conduct and personal morality. Sex in peace operations is arguably subject to greater strictures, occurring as it does during conflict or in post-conflict societies and usually between people of different ages, cultures, religions and socioeconomic status. When sex occurs between people of the same gender, it is often subject to social stigma, taboos and, sometimes, criminal penalties. So why should sex in peace operations be further regulated? Why should the United Nations, a non-governmental organisation (NGO) or a private military security company, such as DynCorp, act as 'the sex police' (Jennings 2008)?

Using a broad definition of regulation as 'the intentional activity of attempting to control, order or influence the behaviour of others' (Black 2002: 1), sex in peace operations is already highly regulated. Drawing on regulatory studies, which see law as a subset of the broader field of regulation, enables us to 'decentre' law and consider other regulatory options. Decentring law is both productive and unsettling for an international lawyer such as myself. Regulatory studies are particularly relevant when the attempts to regulate sex, particularly sexual crimes, in peace operations have primarily taken the form of 'zero tolerance' codes of conduct, which lack the force of law. A prime example in this context is the Secretary-General's bulletin on special measures for protection from sexual exploitation and abuse (UN Secretariat 2003). It might be expected that criminal law would be the most appropriate response to crimes. The problems with applying and enforcing criminal law in the internationalised space of peace operations are precisely what have led the United Nations, NGOs and private military security companies to resort to non-legal forms of regulation.

Building on the work of Charlesworth and Chinkin (2004), I have attempted to view international law through a regulatory lens. Lacking a central authority or sovereign and relying more on horizontal or peer enforcement than on vertical or hierarchical authority, international law is an ideal candidate for regulatory approaches. Surprisingly, there has been little engagement by international lawyers with the field of regulatory studies. However, certain aspects of regulatory theory are helpful in conceptualising the problem of sex in peace operations. In my work, I draw on the foundational theory of responsive regulation put forward by Ian Ayres and John Braithwaite, particularly John Braithwaite's elaboration of networked regulation in developing economies. My work is further informed by the idea of smart regulation advocated by Gunningham, Grabosky and Sinclair (see Gunningham 
and Sinclair, Chapter 8, as well as Grabosky, Chapter 9, this volume). Their willingness to consider non-state actors as potential regulators is useful in a context, such as peace operations, where a functioning host country legal system is often absent. Finally, I raise some feminist questions of regulatory studies-in particular, while regulation offers useful insights into problems, such as sex in peace operations, regulatory studies remain largely oblivious to questions of sex and gender. The issue of sex in peace operations highlights this weakness in regulatory theory to date.

\section{Responsive regulation}

Responsive regulation holds that regulation "be responsive both in what triggers a regulatory response and what the regulatory response will be' (Ayres and Braithwaite 1992: 4). In this model, regulation starts with non-legal mechanisms and reserves state-enforced criminal law for the most serious transgressions where other measures have failed. Responsive regulation draws the regulator's attention to the particular actor and specific situation. So Ian Ayres and John Braithwaite envisage different regulatory responses according to the type of actor involved. Virtuous actors will elicit restorative justice responses; rational actors will respond to deterrence; and incompetent or irrational actors should be incapacitated by the regulator. Command and control or punitive legal responses will be reserved for incompetent or irrational actors. This model also works with a single actor across time, such that a regulator should begin on the assumption that the actor is virtuous, but, if this assumption is demonstrated to be false, based on repeated disregard for the rules, the regulator's response will harden and escalate accordingly (Braithwaite 2005). Designed to be tested through empirical research, responsive regulation is a dynamic model and the type of matters to be dealt with through self-regulation or increasing degrees of punitive intervention need to be adjusted based on experience. As responsive regulation incorporates both punitive and persuasive models of regulation, it is able to invoke the more appropriate strategy based on the situation. Another benefit is that responsive regulation makes punishment cheap, relying as it does on self-regulation in the majority of cases and reserving punitive measures for serious cases, making it attractive to developing countries. Responsive regulation offers promise in dealing with sex in peace operations where state-based law is inadequate. 
Regulatory studies have been developed in industrialised countries characterised by strong legal systems. In this sense, regulatory studies could be seen as a reaction against state-centred law. The international arena is usually seen as lacking a strong central power such as that represented by the state in industrialised economies. Even there, 'few countries exhibit a sufficiently unified or strong state capacity for regulatory power to be capable of sustained manipulation to secure desired regulatory outcomes' (Scott 2003: 158). Peace operations might be seen as an extreme example of the lack of central state power and hence ripe for the application of regulatory mechanisms. A potential critique of regulatory theory is that it assumes that the punitive power of law can be called on when necessary - an assumption less likely to apply in states hosting peace operations. Braithwaite responds to this critique by arguing that responsive regulation relies on a large degree of selfregulation and invokes the punitive power of regulators progressively as the effectiveness of self-regulation diminishes. Nevertheless, responsive regulation appears less likely to work in weaker states, due to lower levels of capacity and the potential for regulatory officials to be corrupted due to poverty, the greater risk of capture and corruption of bureaucrats by business and NGOs' comparative lack of resources (Braithwaite 2005).

Braithwaite's solution to these potential problems with responsive regulation in developing states is 'networking around capacity deficits' (see also Braithwaite, Chapter 7, this volume). Unlike in industrialised countries, where there is reference to the regulatory or even postregulatory state, in developing countries 'under the influence of international organisations, many states are looking to construct the institutions which will make state governance more effective, rather than to dismantle them' (Scott 2003: 167). This is particularly the case in peace operations, where the United Nations usually has a specific mandate to develop institutions as part of a process of state-building. Another approach is for developing states to enrol non-state regulators to cover their weaknesses. These non-state regulators might be foreign states, domestic or international businesses or NGOs. Braithwaite adapts this model to the example of a domestic NGO regulating human rights abuse by either business or the state. The domestic NGO enrols or networks with a range of domestic and international actors, such as international NGOs, foreign embassies, media and the United Nations, when its initial naming and shaming of human rights abuses are not successful. Escalation of naming and shaming through a network of regulators is advocated 'as a path around the developing economy's capacity problem 
for enforcing standards' (Braithwaite 2005: 891). Networked regulation also avoids the problem of legal loopholes or the opportunities for abuse that I argue international law creates.

However, there are two potential weaknesses in networked regulation. The first is the absence of the voices of victims to draw attention to abuses, as empirical research has demonstrated that most victims are reluctant to report (Lattu 2008). This is not necessarily a problem if whistleblowers come forward to report where victims do not. For example, the evidence of two whistleblowers was crucial to the revelation of DynCorp employees' involvement in trafficking in Bosnia. While the whistleblowers were effective in exposing the problem of DynCorp employees' involvement, the biggest sanction faced by those allegedly involved was dismissal-a fate shared by the whistleblowers themselves. The second potential weakness is the fact that, in many cases of sex in peace operations, it is not just one organisational actor, such as an NGO, that is involved, but others as well. This leads to the conclusion that it is insufficient to rely on a limited number of actorssuch as states, NGOs, private military and security companies or the United Nations - to regulate each other. Braithwaite anticipates this problem, giving the example of where only two actors are sufficiently networked to escalate regulation and there is a risk they will collude to protect their own interests, rather than contesting each other. Other actors, such as the media, NGO donors, UN member states (who fund peacekeeping operations), insurance companies, corporate clients and perhaps shareholders, are required as regulators.

\section{Smart regulation}

In Smart Regulation, Gunningham et al. (1998) undertake a comprehensive inquiry into the potential for regulatory instruments to support, neutralise or negate each other (see also Gunningham and Sinclair, Chapter 8, this volume). They call this 'smart regulation'. The main contribution of smart regulation is a detailed consideration of the optimal combination of particular regulatory instruments to achieve desired policy goals:

In the majority of circumstances, the use of multiple rather than single policy instruments, and a broader range of regulatory actors, will produce better regulation. By implication, this means a far more imaginative, 
flexible, and pluralistic approach to environmental regulation than has so far been adopted in most jurisdictions: the essence of 'smart' regulation. (Gunningham et al. 1998: 4)

The proponents of smart regulation are not purist about their instruments, declaring that the goal is to accomplish substantive compliance with regulatory goals by any viable means using whatever regulatory or quasi-regulatory tools that might be available' (Gunningham et al. 1998: 14). They argue against 'single instrument' approaches as misguided and not flexible enough to address all problems in all contexts. Like the proponents of responsive regulation, on which smart regulation builds, they aim to "harness the strengths of individual mechanisms while compensating for their weaknesses by the use of additional and complementary instruments' (Gunningham et al. 1998: 15).

Regulatory theory takes the role of non-state actors as regulators seriously (see Grabosky, Chapter 9, this volume). The economic heritage of regulatory studies is possibly responsible for this, because of the field of economics' interest in markets and its suspicion of the role of the state. Some proponents of free-market ideology call for the 'invisible hand' of the market to take care of business and regard state 'intervention' as ineffective and inefficient. However, while they ascribe a larger and more significant role to non-state actors as regulators than as adherents of a state-based conception of law, most regulatory scholars continue to see a role for the state as 'backstop' or meta-regulator. Braithwaite and Ayres advocate the enrolment of non-state actors such as business and civil society where they are better placed for or more suited to the job of regulation. In environmental regulation, where Gunningham et al. (1998: 250) describe a shift to 'new environmental governance', commercial and non-commercial third parties scrutinise and pressure 'regulatees' (see also Holley, Chapter 42, this volume). Some businesses realised that the reputational benefits of going 'beyond compliance' recouped the initial costs. NGOs frustrated with the slow pace of government intervention believed that they could achieve more by direct negotiation with business. Hence, private, public and non-government stakeholders collaborate towards 'commonly agreed (or mutually negotiated) goals' (Gunningham 2009: 203). Another model is that of enforced self-regulation, in which the state's role should be to act where other regulators have tried but failed. Also referred to 
as 'regulating at a distance', 'light-handed regulation' and 'steering not rowing', mechanisms such as self-regulation and enlisting surrogate regulators continue to depend on their enforcement by the state.

However, there are a number of potential problems with enlisting nonstate actors as regulators. Gunningham identifies the risk of virtually delegating regulatory powers to private actors who may be coopted by the process. Further, there may be a disparity between the financial resources of the parties involved in regulating-for example, the state and private sector being much better funded than NGOs, leading to burnout of NGO volunteers and the inability to voice their concerns effectively due to the power differentials in the forum. Another possibility is that the state merely uses non-state actors as a 'delivery vehicle' for government initiatives, retaining political control but outsourcing responsibility for failures (Gunningham 2009). A further concern is the risk of vigilantism where non-state actors act as delegated or surrogate regulators. Another risk is collusion, where there are only a few actors powerful enough to act as regulators and they collude to protect their own interests.

\section{Sexing regulation}

Regulatory theories assist in understanding sex in peace operations. The scenarios in which sexual crimes are most likely to be committed are those where law is marginalised or its enforcement is dependent on a constellation of political factors. However, regulatory approaches also have limits and weaknesses when applied to sex in peace operations. Having originated in industrialised countries, regulatory studies to this point assume a functioning state and legal system, a rule of law and a basic level of order that may not be applicable to post-conflict societies. While regulatory scholars often argue that it is more efficient for the state to 'steer' rather than 'row', a question that remains unanswered is whether the enrolment of non-state actors as regulators would work if the state were not able to guarantee the non-state actors. Put another way, would 'speaking softly' be effective in the absence of the 'big stick' that the threat of law represents (Braithwaite 1997)? The enrolment of surrogate regulators is not necessarily effective where the reason nonstate actors are being called on to act as regulators is precisely the state's inability to intervene effectively. States hosting UN peace operations are, by definition, unlikely to be effective regulators. Regulatory studies pay detailed attention to the available selection and mix of policy instruments 
but less attention to what the policy aims of regulation should be. There is some discussion of whether policy instruments are pure and unadulterated, or whether their selection affects the design of policy (Black 2003). Clearly, policy aims will be very important, no less so in the case of sex in peace operations. Another striking feature of regulatory studies is the absence of attention to sex. There are a number of studies of regulation of areas that raise sex squarely-for example: sexuality, reproduction and sexual assault (Harding 2011; Sangster 2001; Jackson 2001; Daly 2002). However, these studies might be better understood as feminist scholars engaging with regulation, rather than regulatory scholars engaging with sex (cf. Braithwaite 2006). The questions posed by Charlesworth and Chinkin (2004: 268) remain relevant: 'Who are the regulators; who regulates the regulators? Does regulation affect women and men differently? What gendered patterns of life, work and politics does regulation support?'They highlight the potential for further engagement between regulatory studies and studies of gender and sex.

\section{Further reading}

Dubash, NK and Morgan, B 2013. The Rise of the Regulatory State of the South: Infrastructure and Development in Emerging Economies. Oxford: Oxford University Press. doi.org/10.1093/ acprof:oso/9780199677160.001.0001.

Morgan, B 2015. 'Upside down and inside out: Regulators and regulatory processes in contemporary perspective', in A Sarat and P Ewick (eds), The Handbook of Law and Society. Chichester, UK: John Wiley \& Sons, pp. 150-67. doi.org/10.1002/9781118701430.ch10.

\section{References}

Andreas, P 2009. 'Symbiosis between peace operations and illicit business in Bosnia', International Peacekeeping 16(1): 33-46. doi. org/10.1080/13533310802485518.

Ayres, I and Braithwaite, J 1992. Responsive Regulation: Transcending the Reregulation Debate. Oxford: Oxford University Press.

Black, J 2002. 'Critical reflections on regulation', Australian Journal of Legal Philosophy 27: 1-35. 
Black, J 2003. “Which arrow?”: Rule type and regulatory policy', in C Scott (ed.), Regulation, Law and Legal Theory. London: DartmouthAshgate, pp. 197-220.

Bolkovac, K with Lynn, C 2011. 'The Whistleblower': Sex Trafficking, Military Contractors and One Woman's Fight for Justice. New York: Palgrave Macmillan.

Braithwaite, J 1997. 'On speaking softly and carrying big sticks: Neglected dimensions of a republican separation of powers', University of Toronto Law Journal 47: 305-62. doi.org/10.2307/825973.

Braithwaite, J 2005. 'Responsive regulation and developing economies', World Development 34: 884. doi.org/10.1016/j.worlddev.2005.04.021.

Braithwaite, J 2006. Rape, shame and pride, Address to Stockholm Criminology Symposium, Stockholm, 16 June. Available at: anu.edu. au/fellows/jbraithwaite/_documents/Stockholm_Prize_Address.pdf.

Capps, R 2002. 'Sex-slave whistle-blowers vindicated', Salon, 7 August. Available at: salon.com/2002/08/06/dyncorp/.

Charlesworth, H and Chinkin, C 2004. 'Regulatory frameworks in international law', in C Parker, C Scott, N Lacey and J Braithwaite (eds), Regulating Law. Oxford: Oxford University Press, pp. 246-68. doi.org/10.1093/acprof:oso/9780199264070.003.0013.

Daly, K 2002. 'Restorative justice and sexual assault', in H Strang and J Braithwaite (eds), Restorative Justice and Family Violence. Cambridge: Cambridge University Press, pp. 62-88.

Feminist Majority Foundation 2002. 'US defense contractor held responsible for sex trafficking in Bosnia', Feminist Daily, 7 August. Available at: feminist.org/news/newsbyte/uswirestory.asp?id=6769.

Gunningham, N 2009. 'Environment law, regulation and governance: Shifting architectures', Journal of Environmental Law 21(2): 179212. doi.org/10.1093/je1/eqp011.

Gunningham, N, Grabosky, P and Sinclair, D 1998. Smart Regulation: Designing Environmental Policy. Oxford: Clarendon Press.

Harding, R 2011. Regulating Sexuality: Legal Consciousness in Lesbian and Gay Lives. New York: Routledge. 
Human Rights Watch 2002. Hopes Betrayed: Trafficking of Women and Girls to Post-Conflict Bosnia and Herzegovina for Forced Prostitution. New York: Human Rights Watch.Available at: hrw.org/reports/2002/ bosnia/Bosnia1102.pdf.

Jackson, E 2001. Regulating Reproduction: Law, Technology and Autonomy. Oxford: Hart Publishing.

Jennings, KM 2008. Protecting whom? Approaches to sexual exploitation and abuse in UN peacekeeping operations, Fafo Report 2008(36), Fafo, Oslo. Available at: lastradainternational.org/lsidocs/fafo_ approaches_abuse_0309.pdf.

Kondracki, L (dir.) 2010. The Whistleblower. [Film]. Canada \& Germany: Canada Inc./Barry Films.

Lattu, K 2008. To Complain or Not to Complain: Still the Question. Geneva: Humanitarian Accountability Partnership. Available at: www.alnap.org/resource/10345.

Lloyd-Roberts, S [reporter] 2002. Boys Will Be Boys. [Documentary]. BBC. Available at: news.bbc.co.uk/2/hi/ programmes/correspondent/2043794.stm.

Mendelson, SE 2005. Barracks and brothels: Peacekeepers and buman trafficking in the Balkans, CSIS Report, Center for Strategic and International Studies, Washington, DC. Available at: csis.org/files/ media/csis/pubs/0502_barracksbrothels.pdf.

O'Meara, KP 2002. 'DynCorp disgrace', Insight Magazine, 4 January, 18(4): 12. Available at: connection.ebscohost.com/c/ articles/7159949/dyncorp-disgrace.

Sangster, J 2001. Regulating Girls and Women: Sexuality, Family and the Law in Ontario 1920-1960. Toronto: Oxford University Press. doi. org/10.3138/9781442623507.

Scott, C 2003. 'Regulation in the age of governance: The rise of the post-regulatory state', in J Jordana and D Levi-Faur (eds), The Politics of Regulation. Cheltenham, UK: Edward Elgar, pp. 145-74.

Simm, G 2013. Sex in Peace Operations. Cambridge: Cambridge University Press. doi.org/10.1017/CBO9781139343398. 
United Nations Secretariat 2003. Secretary-General's bulletin on special measures for protection from sexual exploitation and abuse, UN Doc. ST/ SGB/2003/13, 9 October, United Nations Secretariat, New York. Available at: cdu.unlb.org/Portals/0/PdfFiles/PolicyDocC.pdf.

United States Congress 2002. The UN and the sex slave trade in Bosnia: Isolated case or larger problem in the UN system?, Hearing before the Subcommittee on International Operations and Human Rights of the Committee on International Relations, House of Representatives, United States Congress, Washington, DC. Available at: commdocs. house.gov/committees/intlrel/hfa78948.000/hfa78948_0.htm.

United States Department of State 2002. Trafficking in women in Bosnia: Recent events, Information Memorandum, Department of State, Washington, DC. Available at: hrw.org/legacy/reports/2002/ bosnia/1201memo.pdf.

United States Inspector-General 2003. Assessment of DOD efforts to combat trafficking in persons, Phase II, Bosnia-Herzegovina and Kosovo, Report, US Inspector-General, Washington, DC. Available at: hrw. org/reports/2002/bosnia/ig.pdf.

Wilson, J 2002. ' $₫ 100,000$ payout for sacked whistleblower', The Guardian, 27 November. Available at: guardian.co.uk/uk/2002/ nov/27/jamiewilson/print. 
This text is taken from Regulatory Theory: Foundations and applications, edited by Peter Drahos, published 2017 by ANU Press, The Australian National University, Canberra, Australia. 